Egyptian Journal of Aquatic Biology \& Fisheries

Zoology Department, Faculty of Science,

Ain Shams University, Cairo, Egypt.

ISSN $1110-6131$

Vol. 23(4): 365 - 371 (2019)

www.ejabf.journals.ekb.eg

\title{
Application of RAPD-PCR and Morphometric studies on two native Octopodid species from the Mediterranean Sea.
}

\author{
Tarek G. Ali \\ Zoology Department, Faculty of Science, Ain Shams University, Cairo, Egypt. \\ tarekali80@yahoo.com
}

\section{ARTICLE INFO \\ Article History: \\ Received: Oct. 1, 2019 \\ Accepted: Nov. 28, 2019 \\ Online: Nov. 30, 2019}

Keywords:

RAPD-PCR

Morphometry

Octopus

Abu Quir

Alexandria

Mediterranean Sea

\section{ABSTRACT}

Two species of octopuses were collected from Abu Quir, Alexandria, Egypt, Octpus vulgans and Octopus macropus. The mantle muscles were fixed in absolute ethyl alcohol. DNA was extracted and RAPD-PCR was conducted using 4 primers. The distance morphometric analysis of two species was applied on Arm length, Mantle length, Mantle width and body weight. The estimation of genetic distance was 0.55. In addition, morphometric studies showed no significant difference in mantle length and mantle width in both males and females. On the other hand, Arm length and body weight of $50 \%$ of males and females showed significant differences. In conclusion, the result of RAPD- PCR together with the morphometric may suggest that the two species may be two subspecies.

\section{INTRODUCTION}

Octopods are important group due to that they are edible. Most of the previous studies to identify and classify Octopods had been based on morphology, internal anatomy, and skin pattern (Hochberg, et al., 1992; Voss \& Voss, 1983; Hanlon, 1988), the genus Octopus includes about 200 species (Hochberg et al., 1992) of which about 50 have been described in detail (Sosa and Brian, 1995), Voight (1993) used cladistic analysis that have been intered to Octopodid classification. The molecular phylogeny of three Octopodid species in the Maditerranean water was discussed by (Ibrahim, et al., 2006), and the results were compared against six Octopodid species from North pacific Ocean. RAPD- PCR was applied between Octopus vulgaris and $O$. mimus (warnke et al., 2000) the result showed that the two Octopodid species are different in great degree and that was correlated with mitochondrial sequence analysis. Isolation of 18 microsatellite markers of giant pacific octopus, Enteroctopus dofleini and examination of them for 31 individuals was applied (Toussaint et al., 2011). RAPD-PCR was examined on four species of Sepia in Libya (Abdel Razek et $a l ., 2014)$ and showed they are different genetically. The common octopus, O. vularis, Eledone cirrhosa and Dosidicus gigas were understudy by fast real-time PCR analysis (Vieites 2012), and revealed that they are genetically different. The octopus genome was studied in details by Bergman, (2017). In the present study, the two native Octopodid species are distributed not only in Mediterranean Coasts, but in all tropical 
and subtropical water around the world. By application of RAPD-PCR, as a trial to find that this high length in arms of Octopus macropus is due to the ecological response or/and genetic difference between the two species.

Riad and Gabr (2007) studied a comparative morphometric traits of Octopus vulgaris from the Mediterranean and Red Seas in Egypt, using length - weight relationship to compare this species in both population in the two Seas. In 2018, Markaida et al. investigated population structure of Octopus mimus in Ecuador, 4171sampled octopuses were studied using parameters like mantle length (ML) and body weight (BW). Also in the same year (2018), Maulita et al. discussed the patterns of biology and fisheries of Octopus sp. in Indonesia, the work included 402 samples and used the length and weight of the body. There was positive relationship between weight gain and Octopus length. The main difference between Octopus valgaris and $O$. macropus the is length of arms in O. vulgaris has the same length of the body but in O. macropus was three to five times as the length of the body (Roper, 1978).

\section{MATERIALS AND METHODS}

\section{Biological Material:}

Adult 200 samples of two species of Octopus valgaris and O. macropus were collected from shore of Abu-Quir, Alexandria, Egypt. Specimens were placed in absolute alcohol for further molecular analysis in the laboratory at Zoology Department, Faculty of Science, Ain Shams University, and Cairo, Egypt. Samples were dissected and their soft parts carefully isolated and preserved in absolute ethyl alcohol at $-20^{\circ} \mathrm{C}$ until use.

\section{DNA Extraction}

The preserved mantle muscle were cut into small pieces of about $0.5 \mathrm{~cm}$ in length and kept in $\mathrm{ddH}_{2} \mathrm{O}$ in the refrigerator $\left(5^{\circ} \mathrm{C}\right)$ overnight for rehydration.

These samples were centrifuged for one minute at $1400 \mathrm{rpm}$. QIAgen Dneasy tissue kit (QIAgen, Hilden, Germany) was used to isolate and purify the DNA. The procedure used according to the protocol provided by QIAgen catalogue. This kit contained proprietary DNA purification buffers that were used for lysis (ATL and AL buffers), washing (AW1 and AW2 buffers) and elution (AE buffer). 180 $\mu$ l of lysis buffer (ATL) and $20 \mu \mathrm{l}$ of proteinase $\mathrm{K}$ were added to each $1.5 \mathrm{ml}$ tube containing the tissue samples and vortexed for $1 \mathrm{~min}$.

Another $20 \mu \mathrm{l}$ of proteinase $\mathrm{K}$ were added and the samples were centrifuged for 20 seconds. Then, they were incubated at $55^{\circ} \mathrm{C}$ for about 3 hours. Following incubation, $200 \mu 1$ of (AL) lysis buffer were added and the samples were vortexed for 10 seconds. $200 \mu \mathrm{l}$ of ethyl alcohol, were then added, and vortexed for 10 seconds. Samples were spun for $1 \mathrm{~min}$, then the DNA was washed with (AW1) and (AW2) buffers; $500 \mu l$ each. Finally, $200 \mu l$ of (AE) buffer were added to elute DNA samples.

\section{RAPD-PCR}

8 primers were used in the present work but only four of them worked properly (Table 1). Amplifications were performed by modifying the protocol reported by Williams et al. (1990). The $25 \mu \mathrm{l}$ mixture contained $25 \mathrm{ng}$ of template DNA, 1.5 unit Taq Polymerase, 10mM dNTPs (4 types of deoxyribonucleotide triphosphate; dATP, $\mathrm{dCTP}$, dGTP, and dTTP), $10 \mathrm{pM}$ primer, and $25 \mu \mathrm{l}$ of 10x PCR buffer. T-personal thermal cycler (Biometra; Gottingen, Germany) programmed for 45 cycles of $94^{\circ} \mathrm{C}$, $35^{\circ} \mathrm{C}$, and $72^{\circ} \mathrm{C} ; 1$ minute for each temperature. An initial denaturation step (for 3 minutes at $94^{\circ} \mathrm{C}$ ) and a final extension holding (for 10 minutes at $72^{\circ} \mathrm{C}$ ) were included in the first and last cycles, respectively. 
Reaction products $(10 \mu \mathrm{l})$ were resolved by $2 \%$ agarose gel electrophoresis at 85 volt in 1xTAE buffer. The gel was stained with ethidium bromide.

Table 1: The four primers (out of 8) that worked for amplification of DNA extracted from the two species of Octopus.

\begin{tabular}{|l|l|l|l|l|l|l|}
\hline Name & Sequence & $\begin{array}{l}\text { MW } \\
\text { (Molecular } \\
\text { Weight) }\end{array}$ & $\begin{array}{l}\text { OD } \\
\text { (Optical } \\
\text { Density) }\end{array}$ & $\begin{array}{l}\text { GC\% } \\
\text { Percent } \\
\text { Guanine- } \\
\text { Cytosine })\end{array}$ & $\begin{array}{l}\text { Vol for 100 } \\
\text { pmol/ } \mu \mathrm{l}\end{array}$ & Tm (C) \\
\hline OPH-09 & Ś-TGT AGC TTG G-3 & 3099.0 & 2.7 & 60.0 & 250.0 & 32.0 \\
\hline OPH-11 & Ś-CTT CCG CAG T-3 & 2979.0 & 2.4 & 60.0 & 250.0 & 32.0 \\
\hline OPH-12 & Ś-AGG CGC ATG T-3 & 3028.0 & 2.7 & 60.0 & 250.0 & 32.0 \\
\hline OPH-14 & S-ACC AGG TTG G-3 & 3068.0 & 2.8 & 60.0 & 250.0 & 32.0 \\
\hline
\end{tabular}

The DNA fragments that have been specifically amplified were run in $1 \%$ agarose gel; Bands of DNA were photographed by a Polaroid TM-snap 10.0 Megapixel Digital camera Model: PoLSPO 1W.

\section{Calculations of the genetic distance}

The present work applied the calculation according to one of the simplest estimation methods of genetic distance that was based on proportion of shared alleles (Bowcock, et al. 1994). For individual pairwise comparisons, the proportion of common shared alleles (PSA1) was estimated, as follows.

\section{PSA1 $=\Sigma \mathbf{u}$ S $/ 2 \mathbf{~ u}$}

i.e. The number of shared alleles $(\mathrm{S})$ summed the overall loci or bands (u) divided by doubled number of total bands $(2 \mathrm{u})$.

Then, the genetic distance between individuals (DSA1) is estimated by,

\section{DSA1 = 1 - PSA1}

\section{Morphometric Studies}

Morphometric studies were applied on the body weight (bwt), Mantle length (ML), Mantle width (Mw) and Arm length (AL) of 50 males and 50 females of each species. Mean, standard deviation and T test were estimated.

\section{Statistical Analysis}

The data were expressed as mean \pm SD of the octopus body weight, mantle length, mantle width and Arm length. These data were used to elucidate the difference between the measured values. Significance was defined as $\mathrm{P}<0.05$ (Field et al., 2000). Statistical analysis was carried out using SPSS (version 23) incorporated within Microsoft Excel 2010 (Microsoft ${ }^{\circledR}$ Windows 2010) software program.

\section{RESULTS}

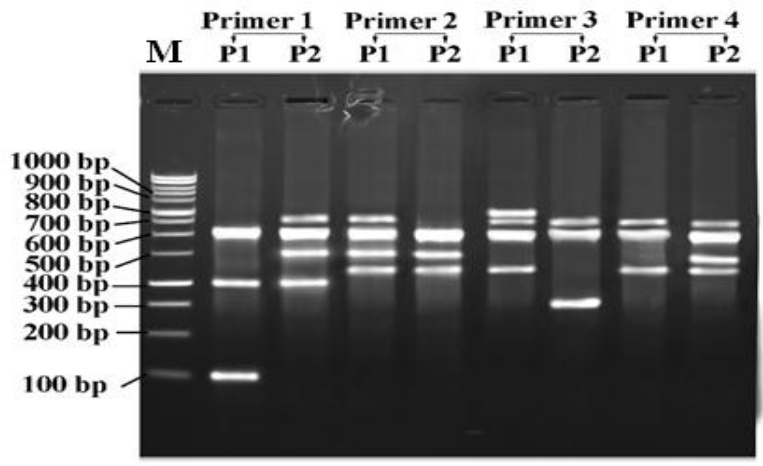

Fig. 1: Photo of agarose gel showing RAPD-PCR Profils produced from two species P1: O. vulgaris, P2: O. macropus, DNA marker (M). 


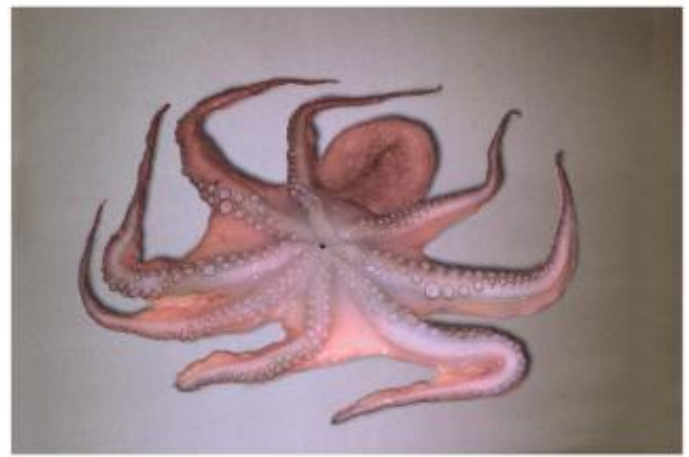

Fig. 2: O. vulgaris

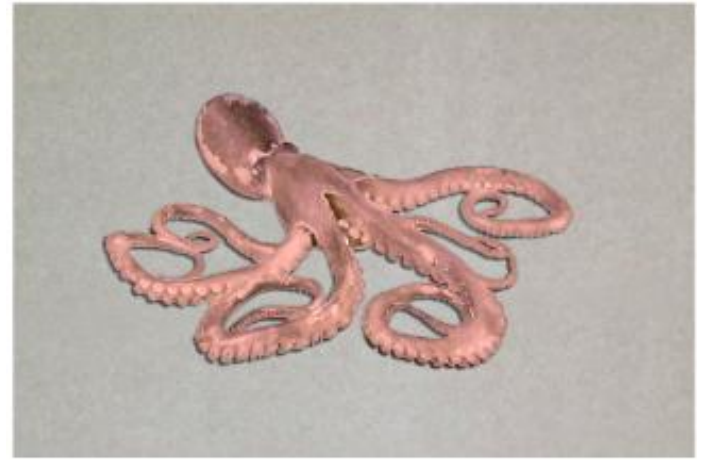

Fig. 3: O. macropus

In the current study, RAPD-PCR analysis was performed on the two species of $O$. vulgari and $O$. macropus, the results were analyzed using the agarose gel electsphrsis (Fig. 1) with four perimers, all bands were ranging between (100-800) base pairs. (bp). The first primer showed three bands with first species: $(100,400$ and 600bp) and four bands with the second species: (400, 500, 600 and 700bp). The second primer resulted in four DNA bands with first species: (450, 500, 600 and $700 \mathrm{bp}$ ) and three bands with second species: (450, 500 and 600bp), the third primer gave four bands with first species: $(450,600,700$ and $800 \mathrm{bp})$ and only three bands with second species: (300, 600 and 700bp). The last primer produced three of DNA bands with first species: (450, 600 and 700bp) and four bands with second species: (450,500,600 and 700bp).

On comparison of the produced bands, there were all together 28 bands or loci at similar and different base pairs measured by base pairs scale according to DNA marker that was used. The similar loci of all bands for the two species were 25 in number, while the different DNA fragments were only three; 100bp (primer 1, P1); 800bp (primer 3, P1) and 300bp (primer 3, P2). See (Table 2) for the values of the bands obtained and the calculation of the genetic distance between the two species.

The estimated genetic distance $\left(\mathrm{D}_{\mathrm{ASi}}\right)$ equaled $(0.55)$ which slightly more than $(0.50)$, so that the two species of $O$. vulgaris and $O$. macropus may be two subspecies.

Table 2: values of amplified DNA bands of the two species revealing over all similar loci ( $\mathrm{S}=25$ and 3 unique bands (bp).

\begin{tabular}{|l|l|l|l|l|}
\hline Primer and species & & \multicolumn{3}{|c|}{ buse pairs (bp) of bands } \\
\hline Primer 1 P1 & $\mathbf{1 0 0}^{*}$ & 400 & 600 & ------ \\
\hline Primer 1 P2 & 400 & 500 & 600 & 700 \\
\hline Primer 2 P1 & 450 & 500 & 600 & 700 \\
\hline Primer 2 P2 & 450 & 500 & 600 & ----- \\
\hline Primer 3 P1 & 450 & 600 & 700 & $\mathbf{8 0 0} *$ \\
\hline Primer 3 P2 & $\mathbf{3 0 0}^{*}$ & 600 & 700 & ---- \\
\hline Primer 4 P1 & 450 & 600 & 700 & \\
\hline Primer 4 P2 & 450 & 500 & 600 & 700 \\
\hline
\end{tabular}

The number of shared alleles; $S=25$

The total number of loci or band $(\mathrm{u})=28$

$P_{\mathrm{SA} 1}=\Sigma \mathrm{u}$ S $/ 2 \mathrm{u}=\mathbf{2 5} / \mathbf{5 6}=\mathbf{0 . 4 5}$

DSA1 $=1-P$ SA1 $=1-0.45=0.55$ 
Table 3: The X (mean), SD (strandard deviation) for males and females O. vulgaris

\begin{tabular}{|l|l|l|}
\hline & \multicolumn{1}{|c|}{ Male } & \multicolumn{1}{c|}{ Female } \\
\hline & \multicolumn{1}{|c|}{$\mathrm{X} \pm \mathrm{SD}$} & \multicolumn{1}{c|}{$\mathrm{X} \pm \mathrm{SD}$} \\
\hline M W & $5.69 \pm 0.131$ & $5.65 \pm 0.129$ \\
\hline ML & $10.86 \pm 0.129$ & $10.60 \pm 0.131$ \\
\hline AL & $11 \pm 0.161$ & $10.5 \pm 0.181$ \\
\hline b wt & $218.7 \pm 1.69$ & $217.5 \pm 1.68$ \\
\hline
\end{tabular}

Table 4: The X (mean), SD (strandard deviation) for males and females O. macropus

\begin{tabular}{|l|l|l|}
\hline & Male & Female \\
\hline & $\mathrm{X} \pm$ SD & $\mathrm{X} \pm$ SD \\
\hline M W & $5.67 \pm 0.131$ & $5.62 \pm 129$ \\
\hline ML & $10.84 \pm 0.128$ & $10.64 \pm 126$ \\
\hline AL & $33.3 \pm 0.300$ & $33 \pm 0.302$ \\
\hline bwt & $239.3 \pm 2.31$ & $240 \pm 2.299$ \\
\hline
\end{tabular}

Table 5: T test of males $O$. vulgaris and O. macropus, T test of females $O$. vulgaris and $O$. macropus

\begin{tabular}{|l|c|c|}
\hline & Male, T test & Female, T test \\
\hline MW & Not Significance $>0.05$ & Not Significance $>0.05$ \\
\hline ML & Not Significance $>0.05$ & Not Significance $>0.05$ \\
\hline AL & Significance $<0.05$ & Significance $<0.05$ \\
\hline bwt & Significance $<0.05$ & Significance $<0.05$ \\
\hline
\end{tabular}

The comparison between males of $O$. vulgaris and $O$. macropus, females of $O$. vulyaris and $O$. macropus. There were four results only significant in Arm length and body weight which is $50 \%$ ( $\mathrm{p}<0.05)$ while four results are not significant in Mantle length and Mantle width $(\mathrm{P}>0.05)$, so that the tested two species may be two subspecies, that correlated with current results of the RAPD-PCR.

\section{DISCUSSION}

The two species; Octopus vulgaris and O. macropus are morphologyically the same except for the long arms of Octopus macropus that may be ecological responses or genetically difference between them.

RAPD-PCR is a good approach for detecting the two species are different or the same (Bergman, 2017). The molecular phylogeny of three octopodid species in the Mediterranean Sea. Octopus vulgaris, Octopus macropus and Eledone moschata was investigated and the results were compared against six octopodid species from North Pacific ocean, the result was that Octopus vulgaris and O. maccopus were different in less degree but Eledore moschata was out group (Ibrahim et al., 2006). However in this study, 0.55 was the result of RAPD-PCR. RAPD-PCR was applied on two species of $O$. vulgans and $O$. mimus (Warnke, et al., 2000) and the result was that the two species are different in great degree and that was correlated with mitochondrial sequence analysis. But in this study. Morphometric data was correlated with results of RAPD-PCR. The common Octopuses, O. vulgans, Eledore Cirrhosa and Dosidicus gigas underwent fast real time PCR (Vieites, 2012) and revealed that they are genetically different but here, they may be two subspecies.

RAPD-PCR was examined on fours species of Sepia in Libya by Abdel Razek et al., 2014 who showed that the four species were four genetically different species. On the present (Riad, 2007) discussed the presence of Octopus vulgaris in the Mediterranean and the Red Seas, based on morphometric analysis, computed lengthweight relationship and found that common octopus in the Red Sea was heavier than 
that captured from the Mediterranean Sea. Moreover, he showed that the environmental conditions in Red Sea are more suitable for $O$. vulgarsis than in the Mediterranean Sea. (Markaida, et al. 2018) used 4171 sampled Octopuses ranged from 56 to $250 \mathrm{~mm}$ in mantle length (ML) and 45 to $3178 \mathrm{~g}$ in body weight in Ecuador waters postulated that sex ratios didn't significantly shift from expected 1:1 in most samples, while in this study $50 \%$ only of morphometric data were significant according, T test. 402 samples of Octopus were investigated by Maulita et al. (2018) in Indonesia, gave that a positive relationship between weight gain and Octopus length and increase in length faster than growth weight. (Emam et al. 2014) found significant difference in all measurements against mantle length in two sexes of Loligo forbesi. However in this study body weight and arm length were significant. In the present work, RAPD-PCR result was 0.55 and morphometric data were $50 \%$ significant only, there was a correlation between the two results and the two octopuses may be two subspecies.

\section{REFERENCES}

Abdel Razek, E.; Ramadan, S. A.; Rashad, M. S. and Mohammed El-Mor (2014). Molecular phylogeny of cuttlefish (sepiidae) and Morphometeric characterization of Sepia officinalis in Ain El-ghazala- Eastern Libya. World J. of zool., 9(3): 178-183.

Bergman, J. (2017). The Octopus: A Mixed - up wonder. Creation. Sci Asso. of Alberta, 20-30.

Bowcock, A. M.; Ruiz-Linares, A.; Tomfohede, J.; Minch, E.; Kidd, J. R. and Cavallisforza, L. L. (1994). High resolution of human evolutionary trees with polymorphic, microsatellite, Nature., 31(368): 6455-6470.

Emam, W. M.; Saad, A. A.; Riad. R. and Alwerfaly, A. H. (2014). Morphometric study and length-weight relationship on the squid Loligo forbesi from the Egyptian Mediterranean waters., Int. J. Env. Sci. and Eng., 5: 1-13.

Hanlon, R. T. (1988). Behavioral and body patterning characters useful in taxonomy and field identification of cephalopods. Malacologia, 29: 247-264.

Hochberg, E. G.; Nixon, M. and Toll, R. B. (1992). Octopoda. In Larval and Juvenile cephalopods: A manual for their Identification. (Sweeney et al., Eds.), smith contrib. Zool., 513: 213-279.

Ibrahim, A. M.; Emam, W. M.; Kenchingtonm E. and Ali, T. G. (2006). Molecular phylogeny of three octopodid species from the Mediterranean water., Egypt. J. Aquat. Biol. and Fish., 10(4): 163-179.

Markaida, U.; Flores, L.; Arias, E. and Mora, E. (2018). Reproductive and population structure of Octopus mimus fished in a Marine protected Area of Ecuador. J. Marine. Biol. Ass. of United Kigdom., 98(6):1383-1389.

Maulita, M.; Dwina, A. Sri, B. and Nunung. S. (2018). Biological and Fisheries aspects of Octopus sp. From waters of buton regency, Indonesia, Inter. of Fish. and aquatic, stud., 6(1): 106-110.

Riad, R. and Gaber, H. R. (2007). Comparative study on Octopus vulgaris from the Mediterranean and Red Sea coasts of Egypt. Egyptian. J. of Aquatic Res., 33:714.

Roper, C.F. (1978) Cephalflds. In FAO species identification sheets for fishery purposes wastern central Atlantic (fishing area 31), Fischer Rome, FAO (6): pag. Var. 
Sosa, K. B. and Brian, H. (1995). The Malecular phylogeny of Five Eastern North pacific Octopus species, Mol. Phyl. Evol., June, 4(2): 163-174.

Toussaint, R. K. Sage, G. K. Tolbt, S. L. and Scheel, D. (2011). Microsatellite marker isolation and development for the giant pacific Octopus Enteoctopus dofleini, Springer Sci. and Bus. Media, 15-30.

Vieites M. J. (2012). Rapid method for controlling the correct labeling products containing (Octopus vulgaris) and main species (Eledone cirrhos and Dosidicus gigas) by fast real - time PCR. Food. Chem. J., 135: 2439-2444.

Voight, R. (1993). Acladistic Reassessment of octopodid classification Malacologia, 35(2): 343-349.

Voss, N. A. and Voss, R. S. (1983). Phylogenetic relationships in the cephalopod family cranchiidae (Aegiopida). Malacologia, 23(2): 397-426.

Warnke, K. S.; Blohm, R. D. and Saint, U. (2000). Rapid differentiation between Octopus vulgaris and O. mimus using RAPD-PCR. J. of zool. Sys. and Evol. Res., 38(2): 119-122.

Williams, J. G.; Kubelik A. R.; Livak, K. J.; Rafalski, J. A. and Tingeg, S. V. (1990). DNA polymorphisms amplified by arbitrary primers are useful as genetic markers., Nucleic arid Res., 25:18 (22): 6531-6535.

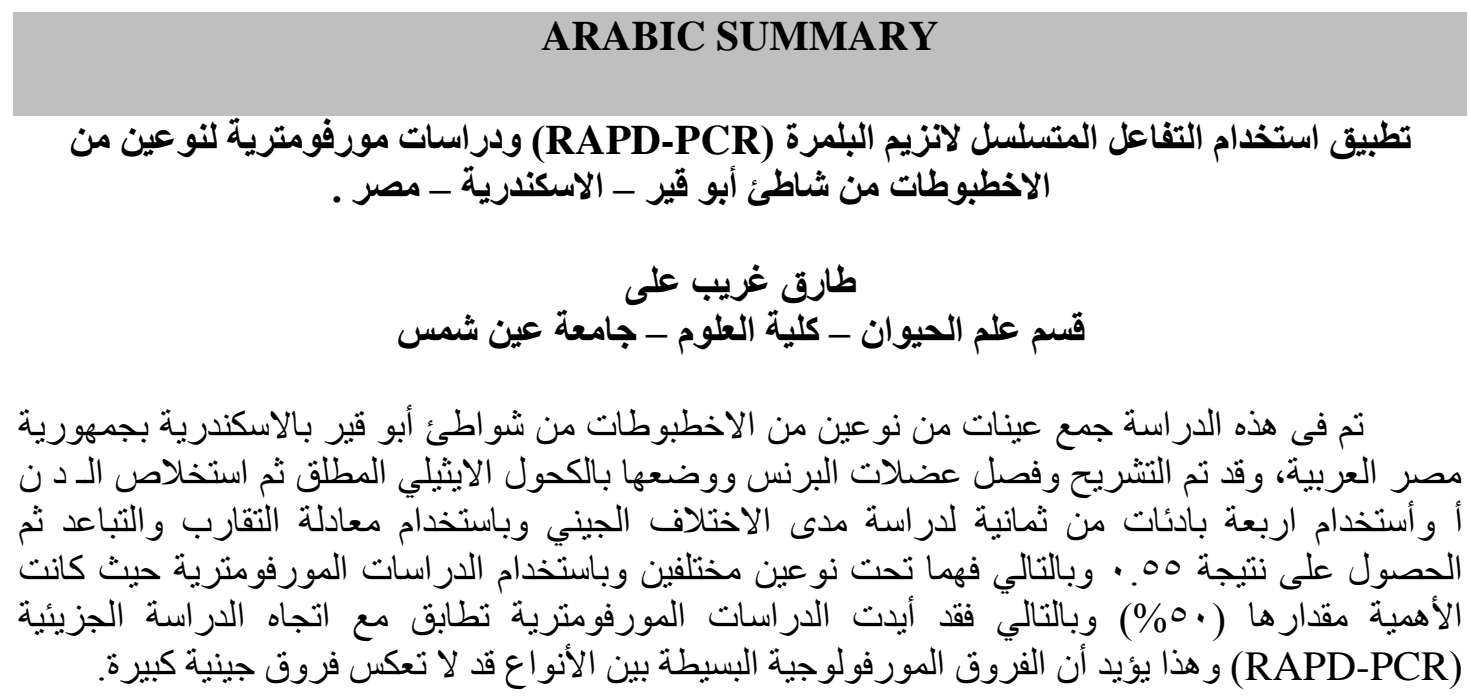

